\title{
BRICS Strategic Communication: The Present and the Future
}

Darya Yu. Bazarkina, Evgeny N. Pashentsev

\author{
Darya Yu. Bazarkina, DSc (Political Science) \\ Institute of Europe of the Russian Academy of Sciences, Moscow, Russia \\ Department of European Integration Research \\ Leading Researcher; \\ Presidential Academy of National Economy and Public Administration, Moscow, Russia \\ Department of the International Security and Foreign Policy of Russia \\ Professor \\ ORCID: 0000-0002-8421-5396 \\ Scopus Author ID: 56027175500 \\ ResearcherID: I-5469-2014 \\ E-mail: bazarkina-icspsc@yandex.ru \\ Address: 11, Bldg. 3 Mokhovaya Str., Moscow 125009, Russia \\ Evgeny N. Pashentsev, DSc (General History), Professor \\ Diplomatic Academy, Moscow, Russia \\ Institute for Contemporary International Studies \\ Leading Researcher \\ ORCID: 0000-0001-5487-4457 \\ Scopus Author ID: 56027099700 \\ ResearcherID: E-2464-2013 \\ E-mail: icspsc@mail.ru \\ Address: 4 Bolshoi Kozlovsky Pereulok, Moscow 107078, Russia \\ DOI: $10.31278 / 1810-6374-2021-19-3-64-93$
}

\section{Abstract}

The article examines the current state and development trends of BRICS strategic communication. Proceeding from the understanding of strategic communication as projection by a state or an interstate entity of long-term 
values, interests, and goals into the minds of audiences by synchronizing activities in all spheres of public life, the authors analyze the main content of BRICS strategic communication and assess its prospects amid the changing world order. The study, conducted from September 2020 to April 2021 on the basis of open sources, made it possible to define the conceptual basis of BRICS strategic communication; specify the factors underlying the formation of BRICS strategic communication engendered by the very nature of cooperation between its member-states; and identify the main problems and trends in the development of BRICS strategic communication. The authors conclude that one of the main messages BRICS is sending to the world through its strategic communication is economic alternativeness, which allows developing nations and countries under pressure from Western political, financial, and economic institutions to remain engaged in global economic processes.

Keywords: BRICS, strategic communication, world order, India, China, Brazil, Russia, South Africa, U.S., New Development Bank.

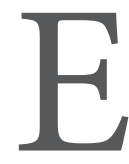
conomic and political contradictions of the modern world and the worsening geopolitical confrontation force all states to find new ways out of the current crisis. At the same time, global problems and the achievement of the UN Sustainable Development Goals set for their resolution require joint international efforts, primarily by countries with substantial economic resources (natural resources and raw materials become the starting point and the basis upon which economies should develop human capital).

New international entities are being created in the 21 st century in order to engage more state and non-state (private sector, civil society institutions, etc.) actors in solving global problems and to prevent the emergence of a monocentric world order. The BRICS grouping is one of them. To explain their goals and expand cooperation, such new actors need a clear and consistent strategic communication (SC) policy that would promise mutual benefit to all participants. "The BRICS countries develop relations among themselves on the basis of non-interference, equality, and mutual benefit. The group is unable to formulate a common view on all issues of mutual interest... However, in 
the face of growing international tensions and the threat of a new global economic crisis, even more destructive than the one in 2008, at the global level, BRICS demonstrates deeds, words, and images of peaceful cooperation between the five countries with different civilizational roots" (Pashentsev, 2015, 2016). This suggests that BRICS strategic communication will develop gradually but steadily.

The purpose of the article is to determine the main content and assess trends and prospects for BRICS SC development amid the changing world order.

The hypothesis of the study is that the current economic, political, and social situation in the world requires the BRICS member states to both close their ranks in the face of common threats and demonstrate their consolidation globally. This forces the group to develop its own strategic communication policy despite the differences in the economic or foreign policies of its member countries. BRICS strategic communication exists de facto but has not been institutionalized yet. At the same time, BRICS already has structures that, if properly developed, can become the basis for such institutionalization.

Research Objectives:

1. Determine the conceptual basis of SC.

2. Identify SC formative factors engendered by the very nature of cooperation among the BRICS member states.

3. Define the main directions, problems, and trends of SC development in BRICS.

These tasks determined the structure of the article. The first paragraph provides an overview of SC studies, determines the theoretical foundations and conceptual framework of the research. Further, we identify the peculiarities of cooperation among the BRICS member states as the basis upon which the grouping is building its SC. Finally, we consider the current state, problems, and development trends of BRICS SC in a number of promising areas.

Methods:

The study was conducted from September 2020 to April 2021 and used open sources. The various areas of BRICS' activities selected for analysis (economic cooperation, communication support for 
international security initiatives, political proposals, etc.) are considered parts of SC, the implementation of which depends on the very nature of the communicator (initiator of communication) and its organizational structure. This led us to raise the question "Who speaks?" formulated by Harold Lasswell (2007), and, when answering it, partly appeal to the theory of political networks (Stone, 2008) (in analyzing the ties of BRICS countries and institutions), as well as to the historical and genetic method. The bulk of primary sources consisted of official BRICS publications, opinion polls, statistics, and media materials. Secondary sources included mainly monographs, academic papers, and analytical reports on the topic of the research and related issues.

\section{CONCEPTUAL FRAMEWORK FOR STRATEGIC COMMUNICATION}

In the 21 st century, a number of countries and intergovernmental organizations have adopted and used the SC concept in public governance and foreign policy. The term and concept of $\mathrm{SC}^{1}$ originated in the United States, where it was elevated to the status of official policy during Barack Obama's presidency (White House, 2010). The SC concept has been adopted by NATO (Private Office of the NATO Secretary General, 2009) and greatly enhanced by the European Union (European Union, 2015; European Union Institute for Security Studies, 2017, 2016a, b, c).

In BRICS, the term 'strategic communication' is found in the political vocabulary of Chinese leaders (CPG, 2010; Mitra, 2018). The first Chinese monograph on SC entitled "Essentials of Strategic Communication" was published in 2011 (Bi and Wang, 2011). India's former Foreign Secretary Nirupama Rao has stressed, “The Indian government needs a cadre of specialists in strategic communication, in policy articulation and projection who also cater to audiences well beyond the domestic audience, non-resident Indians and persons of Indian origin" (Rao, 2016). The "government's strategic communication" is mentioned on the official website of the South African government (GCIS, 2021). In Brazil, the term 'strategic communication' can also be found in government documents (Arantes

Stratcom, StratCom, SC and other acronyms are often used for "strategic communication(s)." 
et al., 2011; Rodrigues, 2013). SC is a de facto element of Russia’s public administration policy as well. Although the term itself is not found in Russian official documents, it is often used in business, politics, and academic literature (Bogdanov, 2017; Pashentsev, 2014; Vinogradova, 2015; Voronov and Glukhikh, 2007; etc.). It is difficult to imagine a successful state in the modern world that would not try one way or another to synchronize its multifaceted activities with professional communication support.

The first Russian academic research to contain a comprehensive analysis of SC as a management discipline was done by Evgeny Pashentsev. Based on his approach (Pashentsev, 2020), the authors define SC as follows: SC is the projection by a state or an interstate entity of certain long-term values, interests, and goals into the minds of domestic and foreign audiences through adequate synchronization of multifaceted activities in all spheres of public life (real results of long-term policy-deeds that all by themselves have a communication impact by improving or harming the reputation of a SC subject) with professional communication support (using "words" and "images"). Without strategic "deeds" there is nothing but a set of long-term communication goals related to key issues. Unless backed up by real actions, such communication turns into vague propaganda, albeit strategic. In addition, SC should not only be effectively synchronized (relevant words and images provided an effective cover even for international aggression and genocide of nations in Nazi Germany), but it also should have an ethical and social dimension so that public trust in and support for strategic communication and the state itself would be long-term and sustainable.

In the field of foreign policy, SC combines the synchronization of influence not only through friendly "deeds, words, and images" projected onto allied states and non-state actors, but also through a wide range of communications as part of psychological warfare (messages addressed to rivals and opponents). This is why when assessing SC in BRICS and the level of its development, it is important to study both positive assessments of the group's "deeds," published by the allies, and the reaction of geopolitical rivals. Both types of 
reaction are caused, above all, not by propaganda (words), but by real achievements of the SC actor.

In the modern world, where states that are economic, technological, and military leaders compete for political influence in the international system, up to the right to determine the nature of the world order, there is no ideological and political vacuum. If a state has no SC of its own, its place will always be taken by SC of other states or/and non-state transnational groups. National SC can emerge or reemerge for a long term thanks to the rise of progressive (acting in the interests of society) forces coming to power. Otherwise, a state can be split forever, like the Soviet Union, or seized by reactionary forces pursuing their own interests and SCs.

Based on the above, SC is understood, firstly, not as communication per se, but communication carried out primarily through state actions. Secondly, it is incorrect to consider SC mainly as a military instrument. It is a strategic tool of public governance (with a military dimension, of course). Thirdly, in order to correct the wrong SC, it is necessary to start by correcting public policy (especially if it is carried out in the interests of reactionary social groups). Fourthly, progressive forces cannot underestimate the role of effective SC as a tool of progressive change. If the state's actions get no response in the hearts and minds of millions of people, if they fail to engage them in conscious activity and do not enjoy successful communication support, they usually get stalled and stymied, actively and not unsuccessfully, by internal and external opponents of progressive national transformations.

$\mathrm{SC}$ is a function of the highest legislative and executive authorities. However, its effectiveness depends not only on the adoption and approval of relevant bills and decrees, but primarily on the effectiveness of the state and the moral health of the entire society. Perhaps a certain share of the state's success always depends on the effectiveness of protoSC-SC of past times that was carried out without an appropriate theoretical base or a modern set of tools. In any case, it must be remembered that even in the most progressive society, SC means the synchronization of government deeds, words, and images with the expected perception and actions by the target audience. 


\section{THE NATURE OF BRICS COUNTRIES' COOPERATION}

Since BRICS' inception, researchers have made different assessments of its legal status, integration and depth (Yifan, 2019; Fadeeva, 2020; Gaidamak, 2017; Takhumova, 2021; Anufrieva, 2020; etc.). Different studies define BRICS as a regional organization (Yifan, 2019), an integration association (Gaidamak, 2017) or an integration grouping (Takhumova, 2021). There are also opinions that BRICS cannot be qualified as any type of organization. For example, Anufrieva (2019, p. 125) believes that the use of "various formulas" in relation to BRICS such as "grouping," "alliance," "partnership," "para-organization," etc. is seen primarily as evidence of its lacking... formal legal, organizational, and institutional characteristics in comparison with "traditional"... international organizations. Therefore, BRICS has not yet acquired the status of an international organization.

Nor does BRICS set integration objectives modeled on regional groupings (adjusted for the transregional nature of the group) such as the European Union. BRICS characterizes itself as "an informal group of states" (BRICS Information Portal, 2021a). And yet there are some features of integration processes within the group. So, unlike international organizations whose efforts are concentrated, as a rule, in one area (Butorina, 2021), BRICS member states, at the initiative of their governments, develop economic, political, scientific, and cultural cooperation among themselves. This gives researchers grounds to talk about the possibility of transforming BRICS into an integration association in the future (Arapova, 2016) (albeit initially on the basis of bilateral agreements and treaties).

Its current fuzzy legal status, of course, cannot but affect the nature of BRICS strategic communication and the pace of its development in terms of "words" and "images," which would certainly help in perceiving the group as a weighty actor in international policy. However, this does not rule out the possibility of developing its SC through "deeds," where the group with its enormous resources, both natural and human (in the field of science, culture, etc.) has a real chance to strengthen the polycentric world order by attracting new supporters. 
In this regard, an important factor in the development of BRICS SC is the creation and development of international structures, such as the New Development Bank (NDB) intended to "mobilize resources for infrastructure and sustainable development projects in BRICS and other emerging economies and developing countries" (New Development Bank, 2014), including through cooperation with other international financial institutions. The role of the NDB is increasing during the coronavirus pandemic. In addition, the development of the New International Payment System (NIPS), highlighted in 2018 by the BRICS Business Council, is among the top priorities (BRICS Pay, 2021), which also brings the group closer to the category of integration associations.

BRICS is developing cooperation in the field of science, technology and innovation. The grouping started creating a legal and political framework for this purpose in 2014 on the basis of the Memorandum of Understanding on Cooperation in Science, Technology and Innovation and the Declaration of the BRICS Presidential Summit on Collaboration for Inclusive Growth and Shared Prosperity in the 4th Industrial Revolution. Work is currently underway to develop the Enabling Framework for the Innovation BRICS Network (Belli, 2020, p. 20, BRICS - Brazil, 2019). In the field of information and communications technology, the BRICS Digital Partnership has been promoted since 2016, and in 2019 a new structure was created-BRICS Science, Technology and Innovation (STI) Architecture-in accordance with the BRICS STI Framework Program (BRICS STI FP, endorsed in 2016). In 2016-2020, BRICS countries supported 93 scientific projects under this program (BRICS STI Framework Program, 2021). The BRICS STI FP Call Secretariat is currently hosted by the Russian Foundation for Basic Research, which undoubtedly creates the conditions for improving the effectiveness of Russia's SC as part of BRICS SC.

The very nature of the BRICS meetings, which constantly address an increasingly growing range of issues, lends development potential to the group by analogy with integration associations. In fact, in 2016 alone, BRICS countries held a Health Ministries meeting (May and December), a Women Parliamentarians Forum (August), a meeting 
of BRICS Ministries for Disaster Management (August), the 2nd meeting of BRICS Environment Ministers (September), a meeting of BRICS Ministers of Foreign Affairs, BRICS Agriculture Ministers' meeting, a meeting of BRICS Ministers of Labor and Employment, a meeting of BRICS Ministers of Education (September), a meeting of BRICS Trade Ministries (October), as well as the BRICS Leaders Informal Meeting as part of the G20 Summit (September) (BRICS Information Portal, 2021b. See more on BRICS' role in armed conflicts: Brosig, 2019). If necessary, such a mechanism can be transformed into a permanent institution like the Council of the European Union, which meets in different formats, depending on the agenda. The BRICS Leaders Informal Meeting, along with major summits, can be institutionalized as a body similar to the European Council. These processes may be intensified in the future amid new global and regional security challenges and threats, more dangerous than the coronavirus pandemic. In this case, more coherent strategic communication can be expected in terms of deeds, words, and images.

The need for a more consolidated response to both traditional and new threats is gradually becoming a catalyst for BRICS' strategic planning. The group has repeatedly voiced a consolidated political position on the issue of armed conflicts. For example, in their Ufa Declaration 2015, BRICS countries expressed "support for the steps of the Russian Federation targeted at promoting a political settlement in Syria" (BRICS, 2015). However, despite the common threat of terrorism, it was not until 2020 that delegations of the BRICS member states for the first time approved the draft BRICS anti-terrorism strategy along with the strategy of economic partnership up to 2025 (Russian BRICS Chairmanship, 2020a).

The Output Document of the 4th Meeting of the BRICS Heads of Prosecution Services, adopted in December 2020, indicates certain synchronization in understanding the positive and negative aspects of the use of advanced technologies in BRICS. While recognizing the relevance of the fight against traditional forms of crime, including terrorist activities, the BRICS Attorneys General also prioritized the combating of crimes committed using information 
and communications technologies (Russian BRICS Chairmanship, 2020b). Unfortunately, the scope of the article does not allow for a comprehensive analysis of BRICS' activities. In addition, the SC of the group, which has not yet reached the level of institutionalization of an integration association or international organization, depends, one way or another, on the SCs of its member states whose interest in group initiatives may differ. However, already now we can note a number of factors and signs indicating the emergence of BRICS SC, both economic and political.

\section{CURRENT STATUS AND DEVELOPMENT TRENDS OF BRICS STRATEGIC COMMUNICATION}

The economic potential of the group and the pace of its development were the main reasons for its transformation into a global actor. This transformation has been described by a Goldman Sachs analyst (O'Neill, 2001). In fact, economic and financial factors are among the main aspects of BRICS SC. This is due not only to the objective reality of the present world order, but also to how the group is seen by the international community. Since BRICS' conception, one of its member states, China, has become the world's largest economy in many respects (for example, in August of 2021, China's GDP based on purchasing power parity ranked first to none in the world with $18.78 \%$ (International Monetary Fund, 2021). In 2019, the total share of BRICS countries in global GDP by purchasing power parity amounted to about $33.3 \%$ (24.2\% in 2020 prices). In addition, BRICS is home to 3.2 billion people, or $42 \%$ of the world population, and accounts for $26 \%$ of the world's land territory (Grigoriev et al., 2020, p. 3).

Since BRICS' most important task is "to advance the reform of international financial institutions, so as to reflect changes in the global economy" (BRICS Information Portal, 2009), the New Development Bank, in our opinion, can be considered one of the most important tools of the group's SC. Great political significance is attached to the Bank as an alternative to the World Bank. An equal distribution of contributions to its capital among member states has a communication effect as well: in the World Bank, the shares and the proportional 
number of votes are distributed unevenly (the United States has the largest share) (Kirton, 2015, p. 21). So, equal participation of the BRICS countries is completely synchronized with the declared task of changing the world financial and economic system to make it fairer and less Western-oriented. Hence, at the level of "words" BRICS SC has introduced a new term-'BRICSonomics' - interpreted as "modern metasubject science that studies the transformational economies that determine the economic development of the modern world" (BRICS University, 2021). Economic alternativeness is one of the main messages BRICS is sending to the world as part of its SC.

NDB-supported projects (in 2020, these were primarily measures to restore the economies of the member states after the crisis caused by the COVID-19 pandemic) reveal the socially oriented nature of BRICS SC. In particular, on December 11,2020, the Bank approved funding for the Indian government's project to overcome the social consequences of the coronavirus pandemic (New Development Bank, 2020).

It can already be stated that the NDB's activities improve BRICS' reputation, which, in turn, can increase its material assets. In 2020, the NDB was rated AA+ by both Standard \& Poor and Fitch, and received an AAA rating by the Japan Credit Rating Agency and the Analytical Credit Rating Agency (ACRA) (New Development Bank, 2021a). The average credit rating of BRICS countries is BBB-. So the NDB was awarded an international credit rating that significantly exceeds the level of confidence in its shareholders, "which enables it to lend to its member countries at very competitive rates" (Maasdorp, 2020). Finally, the Bank is expanding the circle of its shareholders outside the BRICS area. This gives it an opportunity to become a global financial institution in the future.

It should be noted that the potential of the NDB as BRICS' SC tool is far from exhausted for Russia. For example, even at the level of "words," we can see that the list of memorandums of understanding concluded by the NDB mentions only one Russian company (Russian Railways) (New Development Bank, 2021b). There were no memorandums with Russian banking or other financial institutions in this list as of May 16, 2021. This gap not only in "words" but also in "deeds" can negatively 
affect the perception of both BRICS as a cohesive group, and also of Russia in BRICS. At the same time, pure memorandums not supported by real "actions" will turn SC into a series of PR activities.

Science, innovation, and security are a set of interrelated factors needed for SC development. The group's readiness to jointly combat the coronavirus pandemic has not only a practical sense, but also a pronounced communication dimension. In 2020, BRICS reserved $\$ 10$ billion for combating the pandemic and its consequences, as was announced at the 12th summit. The Russian Foreign Ministry explained that the funds would be distributed through the NDB. BRICS leaders "demonstrated complete unanimity in the global confrontation against COVID-19" (Schepin, 2020), specifically, their readiness to jointly develop and produce vaccines.

In addition to the common BRICS projects, bilateral cooperation remains important for the group. For example, during the pandemic, medical supplies weighing more than 90 tons were delivered from India to Russia by air. "Thousands of Russian citizens in India and Indian citizens in Russia returned home by special flights" (Portyakova, 2020). Unfortunately, while China is one of the main trading partners of the other BRICS countries, "trade turnover between the other four countries is small" (Grigoriev et al., 2020) (on a global scale so far). This not only creates the impression that this is an incomplete association, but also from time to time provokes statements in the media that portray bilateral or trilateral relationships between BRICS countries literally as a "counterweight" to other members of the group.

For example, Foreign Policy says: "Neither India-nor Russia, for that matter-wants to be a junior partner to China or the United States. And one way that they can try to avoid that outcome is to remind China and the United States, and the rest of the world, that they can turn back to and bolster each other" (Tamkin, 2020). Such statements, of course, are due to the continuing fast-paced psychological warfare designed to upset relationships between BRICS countries cooperating outside the framework of sanctions imposed by the West. As this warfare intensifies, it would be useful for the group to take steps to further institutionalize its SC. Moreover, in order to draw objective 
economic and political benefits from deepening cooperation, BRICS itself should be further institutionalized at some point (Kheifets, 2015).

Due to China's unprecedented growth and external pressure (including sanctions) from the United States and the EU on both China and Russia, the Russian-Chinese partnership is an object of close attention on the world stage. Amid a trade war unleashed by several Western countries against the Chinese telecommunications company Huawei, its founder Ren Zhengfei announced in September 2020 that the company was moving its investments and operations to Russia. As far back as 2012, the two countries founded the RussiaChina Investment Fund with an initial budget of $\$ 1$ billion in order to invest in high-tech projects (RCIF, 2021). The governments of the two countries designated 2020 as the Year of Russian-Chinese scientific, technical and innovative cooperation (Simes, 2020). As part of this project, the two countries joined forces in studying vaccines against COVID-19 (in particular, the testing of the Russian vaccine in China and the Chinese vaccine in Russia).

This work not only improves the reputation of the two countries, but also evokes a negative reaction from the supporters of the U.S. policy. For example, America Online has described Russian-Chinese projects as "a byproduct of other collaborations that have raised eyebrows in Washington, including on President Trump's intelligence advisory board." It also cited Kevin Hulbert, a former senior intelligence officer in the CIA's Directorate of Operations, as saying: "To see two of your biggest adversaries all of a sudden cooperating, linking arms and working together, that's very concerning to us" (Ingber, 2021). Then the publication sharply changes its tack, moving from health issues to the second Russian-Chinese joint air patrol over the Pacific and joint military exercises. "That's something we've historically never seen happen before," says Hulbert. "The signal is be careful, we could create a real nightmare scenario for you" (Ingber, 2021).

Economic cooperation, the exchange of innovations, and the joint efforts to overcome global threats are inevitably moving into the security domain. This is where BRICS has enormous development potential. Public opinion also appears to be quite agreeable on this 
point. In 2018, Russia's proposal to create BRICS' own Internet independent from the outside world was supported by $58 \%$ of Russians (29\% opposed) (VTsIOM, 2018). In 2017, a platform called CyberBRICS was launched for the exchange of ideas and results of digital research. The platform has been used to promote projects in the field of political regulation of cyberspace and information security. In 2020 CyberBRICS started an international conference project designed "to map existing regulations; to identify best practices; and develop policy suggestions in the areas of cybersecurity governance, Internet access and digitalization of public services in the BRICS countries" (CyberBRICS, 2020).

However, the opponents of BRICS cooperation in the field of information security portray it in an expressly negative way. "Since 2015, China and Russia have drifted closer together when it comes to Internet cooperation ... What this will end up looking like in the long run is accelerating us towards a system of two Internets: A free Internet anchored by U.S. social media platforms and prevalent in the West, and then a closed Internet, different closed Internet systems in China, in Russia, in Iran and elsewhere," says Emerson Brooking, a resident fellow at the Atlantic Council's Digital Forensic Research Lab (Ingber, 2021). This rhetoric is quite consistent with the general spirit of the reports issued by numerous think tanks and media that constantly demonize countries that oppose the U.S. policy.

Naturally, BRICS cooperation and related SC have not escaped the effects of the global crisis. In May 2018, India and China launched their first joint projects in the field of artificial intelligence (AI) and big data. It includes an IT corridor in Dalian and an information technology cooperation platform in Guiyang. In order to establish contacts between Indian and Chinese companies, in 2019 the two countries launched a joint IT initiative for finding and selecting partners (matchmaking), called Sino Indian Digital Collaborative Opportunities Plaza (SIDCOP) - a bilingual AI-based platform (Krishnan, 2018). Prior to this, Indian IT companies had been present in China for more than a decade, but they had mostly serviced Western transnational corporations operating in the Chinese market. The pandemic crisis 
slowed down the projects (for example, as of May 16, 2021, the latest news on the SIDCOP website was dated March 2019), but they may as well serve as a basis for such initiatives for the whole of BRICS.

BRICS strategic communication at the level of "words" and "images" is provided by both the group's institutions and the national media.TV BRICS is an international media network with a "potential audience of 3.5 billion people" and its mission is "to form a united information space of BRICS countries ... while also showing the BRICS countries to the world by immersing the audience in their traditions, history, culture, sports, economics and modern traditions" (TV BRICS, 2021). The network was founded in 2017 at the initiative of the BRICS presidents and currently broadcasts in four languages (Russian, English, Chinese, and Portuguese). Since launching the project in 2017, the TV BRICS team has signed agreements with major information agencies of BRICS countries, including China Media Group (China Radio International, Xinhua, Renmin Ribao, etc.), the South African News Agency, and the Brazilian public television network TV Cultura. "In July 2018 a strategic agreement was signed on exchanging information materials between TV BRICS and the United Nations Department of Public Information" (TV BRICS, 2021).

BRICS' positions are also conveyed globally by the national media and news agencies, primarily TV BRICS' partners. For example, the Chinese news agency Xinhua (Internet versions available in 10 languages) and the Russian news agency Sputnik (29 languages) have global coverage. TV Cultura is the largest public television network in Brazil and Latin America. This situation forces geopolitical opponents to make discrediting statements about the information resources of the BRICS countries (primarily Russia and China). In particular, the European Union's foreign affairs chief Josep Borrell said in March 2021 that the EU "had been under permanent pressure in the past year from countries distorting information and spreading disinformation to advance political interests." However, "while the EU has ramped up its work to debunk disinformation campaigns from Moscow, it has very little resources to study disinformation from China" (Cerulus, 2021). The statement that the European External Action Service (EEAS) lacks 
the "required" resources "to counter Chinese campaigns to influence European politics," can be regarded, of course, as an attempt to get additional funding from EU institutions. Nevertheless, if the BRICS countries had aired only propaganda unsupported by real actions, it would hardly have received so much attention from EU top officials.

A vivid example of accusations thrown at BRICS countries blamed for economic and even cultural expansion is the coverage of Chinese railway construction projects in Africa. In fact, Biodun Odunmbaku-Wilson, Ph.D. Professor of Transportation Engineering (U.S.), commenting on China's construction projects in Nigeria, said, "China is a Communist Nation by design to which every one of her citizens owes an allegiance, which by implication makes every Chinese citizen in any region of the world a spy for the Beijing Government" (Odunmbaku-Wilson, 2020).

In 2021, when describing the Lagos-Ibadan railway in Nigeria, which "is funded by a $\$ 1.3$ billion loan from the Export-Import Bank of China and about $\$ 182$ million from the Nigerian government," Quartz Africa hinted at China's language expansion: "On board the trains the informational video screens feature Chinese nationals; several onboard essential tools such as fire extinguishers, water dispensers, and pressure gauge are in Mandarin..." It then quoted one of the passengers as saying, "They are intentionally letting everyone know China owns it. It is too bold to be coincidental and it seems like there is nothing the Nigerian government can do about it" (Adepoju, 2021). The LagosIbadan railway is one of the most important sections of infrastructure for the Nigerian economy, and China's participation in such projects is often assessed negatively by Western media.

Certain obstacles to the development of BRICS strategic communication-disputes and differences in the member states' foreign policy orientations-are reflected in expert assessments published in the media. For example, following the 12th BRICS summit in 2020, Leonardo Ramos of the Department of International Relations, the Pontifical Catholic University (PUC) Minas in Brazil, noted, "Particularly, these are the relations between India and China, whose current tensions could impact on BRICS. In this process, Russia 
can be a key mediator, for the good sake of countries' cooperation; second, Brazil-China. The Brazilian president has repeated an antiChina position, closing relations with Trump since the beginning of his government. With Biden's victory in U.S. elections, Brazil will have to change something in its foreign policy strategies, and maybe it will do good to its relations with BRICS countries" (Penza News, 2020). The fact that the 12th summit was held amid an ongoing Sino-Indian border dispute was noted by Varaprasad Dolla, Professor in Chinese Studies, Center for East Asian Studies, School of International Studies, Jawaharlal Nehru University. In his expert assessment he addressed a critical issue - the impact of bilateral relations among member states on the future of the entire group. "The member countries must not be oblivious to the bilateral dimension while promoting multilateral forums... Any further bilateral escalation can sound death knell to BRICS' initiative. There can never be a bifurcation and separation of the multilateral from bilateral framework" (Penza News, 2020).

The aftereffects of the Sino-Indian border conflict that started in May 2020 over the disputed Aksai Chin region are still keenly felt. The territory is administered by China, but disputed by India, which includes this region in the union territory of Ladakh. On May 5, 2020, an armed clash occurred between the Indian and Chinese military in the Ladakh region, and on the night from August 29 to August 30, there was a new clash, after which the two countries accused each other of violating previous agreements (RIA, 2021). India and China are trying to settle the conflict diplomatically. In February 2021, they started pulling out more troops and equipment from the disputed region, but the conflict has affected the civilian sphere: soon afterwards, India banned 59 Chinese applications, including TikTok, and later another 47 (Pham, 2020). Negotiations on the supply of the Russian Sputnik $\mathrm{V}$ vaccine to Brazil took a long time: the Brazilian regulator allowed its import and use only in early June 2021, having previously twice refused to approve the vaccine. The Sputnik V developers attributed this to political reasons and U.S. pressure (RBC, 2021). Because of such phenomena in the international arena BRICS SC is forming slower and so far is seen (at least by part of the expert community) as the 
sum of its member states' SCs. This is also borne out by forecasts for the future of BRICS, according to which integration in the group will proceed mainly on the basis of bilateral agreements (see, for example: Arapova, 2016).

The SC of the BRICS countries is under constant pressure from the United States, which seeks to surround Russia and China with a ring of hostile states, giving India a significant role in this process. Against the background of externally good relations between the United States and India, external pressure on the latter is constantly growing as evidenced by a number of events in 2020-2021. For example, in December 2020, the United States for a second time added India on its currency manipulation watchlist (India was added to the list first in December 2018, and later removed in 2019) (Kondepudi, 2021). In early March 2021, the Indian government blasted the report of the American think tank Freedom House (sponsored by the U.S. government), which downgraded India from a "free" country to "partially free." The Indian authorities said that the assessments made by the center were "misleading, incorrect and misplaced." In an eloquent report entitled "Democracy under Siege," Freedom House said that India seemed to have abandoned its potential to serve as a global democratic leader under nationalist Hindu Prime Minister Narendra Modi and the ruling Bharatiya Janata Party (Reuters, 2021). On April 9, 2020, the Indian Ministry of External Affairs announced that it had "conveyed its concerns regarding this passage through our EEZ to the government of the USA through diplomatic channels" (Unnithan, 2021). On April 23, 2021, India's central bank restricted the American Express and Diners Club payment systems from adding new customers starting May, citing violation of local data-storage rules. "The rules require payments firms to store all Indian transaction data within servers in the country" (Singh, 2021). In April 2021, the Indian government told Twitter to remove posts critical of its fight against coronavirus, which "misled" the audience or caused panic. "We cannot allow fake news that harms the

2 Freedom House, an international non-governmental organization, has been ranking "free" countries since 1973. Experts annually update the rating and assign the status of freedom to states. In total, there are three such statuses: "free," "partially free," and "not free." 
country," BJP national spokesperson Gopal Agarwal told the BBC (BBC News, 2021). The United States belatedly responded to the pandemic situation in India, which apparently required assistance to the country (Rajghatta, 2021; Chaudhary and Czuczka, 2021). The imposition of sanctions against India under the Countering America's Adversaries Through Sanctions Act (CAATSA) in connection with the planned purchase by India of the Russian Triumph S-400 surface-to-air missile systems can damage relations between the U.S. and India, former U.S. ambassador to India Kenneth I. Juster said (2021). All these actions can be seen as interference in India's internal affairs and attempts to force it to deviate from an independent course, which is unlikely to get a positive response in Indian society.

Despite the challenges, in general, new strategic planning documents, expert assessments, and the nature of BRICS-supported decisions show that the member states are rapidly drifting closer together in response to growing global challenges and threats. Given this, the authors of the article would like to be optimistic and assume that the crisis will reveal new points of convergence and areas for the development of the group's SC.

Based on the analysis of the conceptual and institutional frameworks and the current state of SC in BRICS, it can be concluded that it needs to be developed further amid mounting international tensions. Existing studies of BRICS' structure, legal status and economic activity show that the group has not only a constantly improving base for the development of SC, but also the potential to become a transregional integration association. Based, in part, on the results obtained by experts in the fields of political science, law and economics, this study establishes the existence of de facto SC in BRICS. This article can be a starting point for studying the group's SC more thoroughly, and for developing practical recommendations for entities that carry it out.

To assess the synchronization of words, deeds, and images transmitted by BRICS, and to evaluate the effectiveness of its SC, J. 
Kirton's approach (2015) can be used. Kirton put forward a number of criteria for measuring the success of BRICS summits (domestic political management, deliberation, direction setting, decisionmaking, delivery). To assess the effectiveness of SC, these criteria can be supplemented with some more indicators such as the level of public trust in BRICS (both in the member states and other countries), real cooperation with BRICS institutions in the world and readiness for such cooperation, the number and intensity of public actions aimed at supporting BRICS' initiatives, and the activity of BRICS' supporters and opponents in the media and social networks.

A comparative analysis of strategic planning, its implementation and coverage in the member states offers great opportunities for exploring possibilities for building and developing BRICS SC. Comprehensive research studies addressing this issue can be used in practice when creating a BRICS SC center. At the same time, in doing so it would also be advisable to use the resources of the existing BRICS Think Tank Council (BTTC) or the International Alliance of BRICS Strategic Projects.

It is believed that as the BRICS labor market develops and countries swap employees, including highly skilled personnel, diasporas will play an increasingly growing role as informal agents of the BRICS member states' SCs. In this regard, it would be very important to examine the possible role of diasporic diplomacy in molding the SC of the entire group. Another important issue to study is contradictions between BRICS countries in shaping up the group's SC.

The study suggests that BRICS' main message to the world community and the basis of its SC is economic alternativeness which allows developing nations and countries under pressure from Western political, financial, and economic institutions to remain engaged in global economic processes. Naturally, BRICS (even with China led by the Communist Party as its member) operates within the framework of the existing capitalist world order and does not offer an alternative socioeconomic model (and does not have such a goal). The political component of the group's SC is also extremely important: the message BRICS sends through its economic, technological, cultural, educational, 
and other initiatives clearly indicates support for a polycentric world. This message (against the background of economic rivalry between the United States and China) becomes an object for counter-narratives being developed by Western media and political circles, which require a skillful and timely response.

At the same time, it must be admitted that BRICS SC is in a formative stage and is often seen in the international arena as the sum of its member states' SCs. In this situation, the SC of the group directly depends on the SCs of its member countries that lead the way in the economy, innovations, and social sphere. At the same time, the following factors influence the development of SC in BRICS as an international association:

1. Commonality of problems. It would be worth mentioning sanctions imposed by the collective West on Russia and China, external pressure on India in an attempt to push it towards confrontation with BRICS members, and, possibly, elements of pressure on Brazil (some signs of its can be found in: Elmaazi, 2021), which forced the country to ban the import of the Russian vaccine against COVID-19. Naturally, in the face of common problems, the geographical closeness of Russia, India, and China (which they do not share with Brazil and South Africa) contributes to their mutual rapprochement (although there are also contradictions that hinder it and complicate the development of common SC). However, global political processes and the challenges of economic cooperation will most likely encourage the BRICS countries to get closer together as a transregional association. This is also necessitated by current military dangers and threats, and such global problems as international terrorism, environmental crises, etc.

2. Economic ties and political cooperation. China's growing economic influence in Africa and Latin America, demand for Russian vaccines and Indian medical products, and militarytechnical cooperation between the BRICS countries clearly indicate that short-term disagreements on certain issues cannot stop mutually beneficial partnerships in various sectors. 
3. BRICS' communication potential (media coverage, the number of broadcasting languages, etc.) makes it possible to effectively convey the member states' agenda to audiences around the world, which has been recognized by the group's opponents.

4. Institutions, the process and initial results of strategic planning capable, if properly developed and if such a need arises, of starting to transform the group into a transregional integration association.

At the same time, BRICS is facing factors that hamper both the rapprochement of countries and the development of the entire group's $\mathrm{SC}$. One of them is an objective factor of geographical distance between certain BRICS states, as a result of which their governments have to pay more attention to external pressure from BRICS' opponents. The disconnecting impact of the pandemic complicates both diplomatic and scientific cooperation among the BRICS states. Psychological campaigns aimed at disrupting the group's cooperation and discrediting some of its members in the eyes of the others remain a major challenge for SC. It would therefore be advisable for BRICS to take coordinated measures to ensure psychological security.

\section{References}

Accent, 2021. Huawei smozhet uchastvovat' v stroitelstve brazilskih setei 5G [Huawei Will Participate in the Construction of Brazilian 5G Networks]. iXBT. com [online]. Available at: www.ixbt.com/news/2021/01/17/huawei-smozhetuchastvovat-v-stroitelstve-brazilskih-setej-5g.html [Accessed 15 May 2021].

Adepoju, P., 2021. Nigeria's Ambitious Chinese-Built Rail Project Is Keen to Avoid a Familiar Problem. Quartz [online]. Available at: qz.com/africa/1958964/ nigerias-china-built-railway-has-to-avoid-debt-pitfalls/?utm_source=YPL [Accessed 30 April 2021].

Anufrieva, L., 2020. BRICS: Legal Nature and Principles of Cooperation. Actual Problems of Russian Law, 1(12), pp. 123-133.

Arantes, O. M. N., Silveira, J. M. F. J. D., Borges, I. D. C., Capalbo, D. M. F., Schneider, D. R. S., Gattaz, N. C. and Lima, E. D. S., 2011. Desenvolvimento de comunicação estratégica sobre biosegurança de plantas geneticamente 
modificadas: o caso do projeto LAC-Biosafety no Brasil. Congresso interinstitucional de iniciação científica, (5).

Arapova, E., 2016. Perspektivy ekonomicheskoi integratsii $\mathrm{v}$ formate BRIKS [Prospects for Economic Integration within BRICS]. Rossisky vneshnejekonomichesky vestnik, 2.

BBC News, 2021. India Covid: Anger as Twitter Ordered to Remove Critical Virus Posts. News.yahoo.com [online]. Available at: news.yahoo.com/indiacovid-outrage-government-orders-051250029.html [Accessed 1 May 2021].

Belli, L., 2020. CyberBRICS: A Multidimensional Approach to Cybersecurity for the BRICS. In: L. Belli (ed.), forthcoming). CyberBRICS: Mapping Cybersecurity Frameworks in the BRICS. Rio de Janeiro: FGV Direito Rio, pp. 17-57.

BRICS - Brasil, 2019. Enabling Framework for the Innovation BRICS Network (“iBRICS Network"). BRICS - Brasil 2019 [online]. Available at: brics2019. itamaraty.gov.br/images/documentos/Enabling_Framework_iBRICS_ Network_Final.pdf [Accessed 16 January 2021].

Bi, Y. and Wang, J., 2011. Zhan luechuanbo gang yao [Essentials of Strategic Communication]. Beijing: Guo jiaxingzhengxue yuan chu ban she [State Administration College Press].

Bogdanov, S., 2017. Strategicheskie kommunikatsii: kontseptualnye podkhody i modeli dlya gosudarstvennogo upravleniya [Strategic Communication: Conceptual Approaches and Models for Public Administration]. Gosudarstvennoe upravlenie. Elektronny vestnik, 61, pp. 132-152.

BRICS, 2015. VII BRICS Summit. Ufa Declaration (Ufa, Russian Federation, 9 July 2015). BRICS Information Portal [online]. Available at: infobrics.org/files/ pdf/27.pdf [Accessed 06 May 2020].

BRICS Information Portal, 2009. Joint Statement of the BRICS Countries' Leaders (Yekaterinburg, Russia, June 16, 2009) [online]. Available at: infobrics.org/ document/3/ [Accessed 16 January 2021].

BRICS Information Portal, 2021a. History of BRICS [online]. Available at: infobrics.org/page/history-of-brics/ [Accessed 15 January 2021].

BRICS Information Portal, 2021b. Documents 2016 [online]. Available at: infobrics.org/documents/2016/ [Accessed 16 January 2021].

BRICS Pay, 2021. BRICS Pay-New International Payment System (NIPS) [online]. Available at: bricspay.org.ru/ [Accessed 19 January 2021]. 
BRICS STI Framework Programme, 2021. Pre-Announcement BRICS STI Framework Programme Response to COVID-19 Pandemic Coordinated Call for BRICS Multilateral Projects 2020 [online]. Available at: brics-sti.org/index. php?p=new/26 [Accessed 16 January 2021].

BRICS University, 2021. Global Education. Extremely Competitive Advantage. Unibrics.ru. Available at: unibrics.ru/ [Accessed 1 May 2021].

Brosig, M., 2019. The Role of BRICS in Large-Scale Armed Conflict. Cham: Palgrave Macmillan.

Butorina, O., 2021. Ponyatie regionalnoi integratsii: novye podhody [The Concept of Regional Integration: New Approaches]. Polit.ru [online]. Available at: polit.ru/article/2006/04/10/butorina/ [Accessed 15 January 2021].

CPG of the People's Republic of China, 2010. China Pledges to Strengthen Strategic Communication with ROK. Central People's Government of the People's Republic of China [online]. Available at: www.gov.cn/english/2010-08/11/ content_1677191.htm [Accessed 15 May 2019].

Cerulus, L., 2021. Borrell: EU Doesn't Have Resources to Fight Disinformation from China. Politico [online]. Available at: www.politico.eu/article/josep-borrelleu-doesnt-have-resources-fight-disinfo-china/ [Accessed 30 April 2021].

Chaudhary, A. and Czuczka, T., 2021. On Slow US Response to India's Covid Crisis, China's Strategic Digs. NDTV.com [online]. Available at: www.ndtv. com/world-news/superficial-closeness-chinas-digs-over-us-response-to-indiacrisis-2422329 [Accessed 1 May 2021].

CyberBRICS, 2020. Digital Sovereignty in the BRICS Countries: Data, Infrastructure, and Services [Call for Papers] [online]. Available at: <cyberbrics. info/call-for-papers-cyber-sovereignty-in-the-brics-countries-datainfrastructure-and-services/> [Accessed 19 January 2021].

Elmaazi, M., 2021. US Secretly 'Persuaded' Bolsonaro to Reject Russian COVID Vaccine, Investigative Journalist Explains. Sputniknews.com [online]. Available at: sputniknews.com/interviews/202103181082380041-us-secretly-persuadedbolsonaro-to-reject-russian-covid-vaccine-investigative-journalist-explains/ [Accessed 1 May 2021].

European Union Institute for Security Studies, 2016a. In-Depth Analysis. EU Strategic Communications with a View to Counteracting Propaganda. Brussels: European Parliament. 
European Union Institute for Security Studies, 2016b. Towards an EU Global Strategy - Consulting the Experts. Paris: EUISS.

European Union Institute for Security Studies, 2016c. Strategic Communications. East and South. Report 30. Paris: EUISS.

European Union Institute for Security Studies, 2017. Hybrid Threats and the EU. Conference Report. Paris: EUISS.

European Union, 2015. EU Action Plan on Strategic Communication. Ref. Ares(2015)2608242 - 22 June 2015. European Union External Action Service (EEAS).

Fadeeva, I., 2020. Assessment of the Impact of Disintegration Manifestations in the BRICS on the Economy of the Group. Azimuth of Scientific Research: Economics and Administration, 9(31). DOI: https://doi.org/10.18611/2221-32792017-8-4-127-144.

Gaidamak, A., 2017. Mezhgosudarstvennaya integratsiya stran BRIKS na primere golosovaniya v OON [Interstate Integration of the BRICS Countries: The Case of UNVoting]. International Journal of Humanities and Natural Sciences, (3).

GCIS, 2021. Cluster Supervision. Government Communication and Information System (GCIS), Republic of South Africa [online]. Available at: www.gcis.gov.za/ content/about-us/chief-directorates/clusters [Accessed 15 May 2021].

Grigoriev, L., Pavlyushina, V., Kheifets, El., Muzychenko, E., Kheifets, Ye., 2020. Vzaimnaya torgovlya stran BRIKS [Mutual Trade of the BRICS Countries]. Byulleten' o tekushchikh tendentsiyakh mirovoi ekonomiki. Vol. 55 [online]. Available at: ac.gov.ru/uploads/2-Publications/\%D0\%B0\%D0\%BF \%D1\%80_2020_web.pdf [Accessed 19 January 2021].

Ingber, S., 2021. Analysts Say Growing China-Russia Alliance Presents New Threats. AOL [online]. Available at: www.aol.com/analysts-growing-chinarussia-alliance-191701286.html [Accessed 18 January 2021].

International Monetary Fund. 2021. GDP Based On PPP, Share Of World [online]. Available at: <www.imf.org > [Accessed 19 January 2021].

Juster, K., 2021. Remove a Sanctions Cloud from U.S.-Indian Relations. War on the Rocks [online]. Available at: warontherocks.com/2021/04/remove-asanctions-cloud-from-u-s-indian-relations/ [Accessed 1 May 2021].

Kheifets, B., 2015. Prospects of BRICS Institutionalization. Voprosy Ekonomiki, 8, pp. 25-42. 
Kirton, J., 2015. Explaining the BRICS Summit Solid, Strengthening Success. International Organisations Research Journal, 10(2), pp. 9-38.

Kondepudi, R., 2021. Explained. US Adds India to Currency Manipulator Watchlist: What Does It Mean? Moneycontrol [online]. Available at: www. moneycontrol.com/news/india/explained-us-adds-india-to-currencymanipulator-watchlist-what-does-it-mean-6790691.html [Accessed 1 May 2021].

Krishnan, A., 2018. India, China Launch First Joint Projects in Big Data, AI. India Today [online]. Available at: www.indiatoday.in/india/story/india-chinalaunch-first-joint-projects-in-big-data-ai-1242989-2018-05-27 [Accessed 11 May 2020].

Lasswell, H., 2007. The Structure and Function of Communication in Society. İletişim kuramve araştırma dergisi [Communication Theory Research Journal], 24, pp. 215-228.

Maasdorp, L., 2020. COVID-19: How Multilateral Development Banks Can Lead Through a Crisis. World Economic Forum [online]. Available at: www. weforum.org/agenda/2020/07/brics-new-development-bank-leads-memberstates-through-the-covid-19-crisis/ [Accessed 15 May 2021].

Mitra, D., 2018. India, China Agree to Improve Strategic Communication at the End of Informal Talks. The Wire, 29 April [online]. Available at: https://thewire. in/diplomacy/india-china-agree-to-improve-strategic-communication-at-theend-of-informal-talks [Accessed 18 August 2021].

New Development Bank, 2014. Agreement on the New Development Bank. Fortaleza, July 15 [online]. Available at: www.ndb.int/wp-content/themes/ndb/ pdf/Agreement-on-the-New-Development-Bank.pdf [Accessed 16 January 2021].

New Development Bank, 2020. COVID-19 Emergency Program Loan for Supporting India's Economic Recovery [online]. Available at: www.ndb.int/ covid-19-emergency-program-loan-for-supporting-indias-economic-recovery/ [Accessed 16 January 2021].

New Development Bank, 2021a. Credit Ratings [online]. Available at: www.ndb. int/investor-relations/credit-ratings/ [Accessed 17 January 2021].

New Development Bank, 2021b. List of Current MoUs [online]. Available at: www.ndb.int/partnerships/list-of-current-mous/ [Accessed 16 January 2021].

O’Neill, J., 2001. Building Better Global Economic Brics. Global Economics Paper, 66 [online]. London: Goldman Sachs Economic Research Group. Available at: 
www.goldmansachs.com/insights/archive/archive-pdfs/build-better-brics.pdf [Accessed 19 January 2021].

Odunmbaku-Wilson, B., 2020. Halt All Chinese Loans for Nigeria Railways Now. The Guardian Nigeria News - Nigeria and World News [online]. Available at: guardian.ng/opinion/halt-all-chinese-loans-for-nigeria-railwaysnow/\#: :text=The\%20Railway\%20projects\%20in\%20Nigeria\%20are $\% 20$ many\%20and,\%E2\%80\%93\%20Minna\%2C\%20Minna\%20\%E2\%80\%93\%20 Abuja\%2C\%20Ibadan\%20\%E2\%80\%93\%20Kano [Accessed 30 April 2021].

Pashentsev, E., 2015. Strategic Communication of BRICS: Myth or Reality? L'Eurispes [online]. Available at: www.leurispes.it/strategic-communication-ofbrics-myth-or-reality/ [Accessed 16 May 2021].

Pashentsev, E., 2016. Strategicheskaya kommunikatsiya BRIKS i ugrozy primeneniya prognosticheskogo oruzhiya [BRICS Strategic Communication and the Threat of the Use of Prognostic Weapons]. Strategicheskaya stabilnost', 2(75).

Pashentsev, E. (ed.), 2020. Strategic Communication in EU-Russia Relations: Tensions, Challenges and Opportunities. Cham: Palgrave Macmillan.

Pham, S., 2020. India Bans More Chinese Apps as Tensions Remain High. CNN [online]. Available at: edition.cnn.com/2020/11/25/tech/india-bans-chineseapps-hnk-intl/index.html [Accessed 24 June 2021].

Penza News, 2020. BRICS Leaders Synchronize Watches on Major International Issues. Analysis. Eurasia Review [online]. Available at: www.eurasiareview. com/01122020-brics-leaders-synchronize-watches-on-major-internationalissues-analysis/ [Accessed 16 January 2021].

Portyakova, N., 2020. Indiya ne verit v torgovuyu voinu [India Does Not Believe in a Trade War]. Izvestiya [online]. Available at: iz.ru/1038535/nataliiaportiakova/indiia-ne-verit-v-torgovuiu-voinu [Accessed 18 January 2021].

Private Office of the NATO Secretary General, 2009. NATO Strategic Communications Policy. Public Intelligence [online]. Available at: info. publicintelligence.net/NATO-STRATCOM-Policy.pdf [Accessed 15 May 2021].

Rajghatta, C., 2021. President Biden Phones PM Modi to Discuss Covid. US Jolted into Action after Criticism of Silence over India's Plight. Times of India [online]. Available at: timesofindia.indiatimes.com/india/covid-19-pm-modispeaks-to-us-president-biden-over-the-phone/articleshow $/ 82262800 . \mathrm{cms}$ [Accessed 1 May 2021]. 
Rao, N., 2016. The Pursuit of National Goals Needs Strategic Communication, Not Chaos and Noise. The Wire [online]. Available at: thewire.in/externalaffairs/india-must-consider-strategic-communication-to-achieve-national-goals [Accessed 15 May 2021].

RIA, 2021. Pochemu protivostoyanie na granitse Indii i Kitaya prodolzhaetsya bolshe goda [Why the Confrontation on the India-China Border Continues for More Than a Year]. Federalnoye agentstvo novostei, 1 [online]. Available at: riafan.ru/1450887-pochemu-protivostoyanie-na-granice-indii-i-kitayaprodolzhaetsya-bolshe-goda [Accessed 24 June 2021].

RBC, 2021. Brazilija razreshila primenenie i vvoz "Sputnika V" [Brazil Has Endorsed the Use and Import of Sputnik V]. RBC [online]. Available at: www. rbc.ru/society/05/06/2021/60bac6bf9a79474262306d82 [Accessed 24 June 2021].

Reuters, 2021. Indian Government Blasts US Think Tank That Calls Country Only 'Partly Free'. CAN [online]. Available at: www.channelnewsasia.com/news/ asia/indian-government-blasts-us-think-tank-that-calls-country-only--partlyfree--14344796 [Accessed 1 May 2021].

Rodrigues, N., 2013. A Comunicação Estratégica no Exército Brasileiro: A udança do perfil das Operações Psicológicas, sua integração com o Sistema de Comunicação Social e os interesses da Força. Dissertação [Strategic Communication in the Brazilian Army: The Change in the Profile of Psychological Operations, Their Integration with the Social Communication System, and the Interests of the Force]. PhD. Rio de Janeiro: Escola de comando e estadomaior do exército Escola Marechal Castello Branco.

RCIF, 2021. About The Fund. Russia-China Investment Fund [online]. Available at: en.rcif.ru/about/about-more.html [Accessed 18 January 2021].

Russian BRICS Chairmanship, 2020a. BRICS Counter-Terrorism Strategy. [online]. Available at: eng.brics-russia2020.ru/images/114/81/1148168.pdf [Accessed 17 January 2021].

Russian BRICS Chairmanship, 2020b. Outcome Document of the 4th Meeting of the BRICS Heads of Prosecution Services [online]. Available at: https://eng. brics-russia2020.ru/images/134/25/1342574.pdf [Accessed 17 January 2021].

Schepin, K., 2020. Kitayu est' chem podelitsa [China Has a Lot to Share With]. Rossiyskaya Gazeta [online]. Available at: rg.ru/2020/11/18/briks-podalaprimer-borby-s-koronavirusom.html [Accessed 18 January 2021]. 
Simes, D., 2020. Russia, China Strengthen Economic Cooperation, Advance Effort to Move Away from US Dollar. CNSNews.com [online]. Available at: www.cnsnews.com/index.php/article/international/dimitri-simes/russia-chinastrengthen-economic-cooperation-advance-effort [Accessed 18 January 2021].

Singh, M., 2021. India Restricts American Express from Adding New Customers for Violating Data Storage Rules. Yahoo! Finance [online]. Available at: finance. yahoo.com/news/india-restricts-american-express-adding- 171754666. html?soc_src=community\&soc_trk=ma [Accessed 1 May 2021].

Stone, D., 2008. Global Public Policy, Transnational Policy Communities, and Their Networks. Policy Studies Journal, 36(1), pp.19-38.

Takhumova, O., 2021. Osnovnye napravleniya sotrudnichestva Rossii v ramkakh integratsionnoi gruppirovki BRIKS [Main Areas of Russia’s Cooperation within the BRICS Integration Group]. In: Rossiya i mirovoye soobshchestvo pered vyzovami nestabilnosti ekonomicheskikh i pravovykh sistem [Russia and the World Community Faced with the Challenges of the Unstable Economic and Legal systems]. Ufa: Aeterna, pp.231-233.

Tamkin, E., 2020. Why India and Russia Are Going to Stay Friends. Foreign Policy [online]. Available at: foreignpolicy.com/2020/07/08/russia-indiarelations/ [Accessed 19 January 2021].

TV BRICS, 2021. About TV BRICS. TV BRICS [online]. Available at: tvbrics. com/en/about/ [Accessed 30 April 2021].

Unnithan, S., 2021. Why Is the US Navy in India's Backyard? India Today [online]. Available at: www.indiatoday.in/india-today-insight/story/why-isthe-us-navy-in-india-s-backyard-1789264-2021-04-09 [Accessed 1 May 2021].

Vinogradova, E., 2015. Rol' strategicheskoi kommunikatsii vo vneshnei politike ALBA (na primere otnosheniy so stranami ES) [The Role of Strategic Communication in ALBA's Foreign Policy: Relations with EU Member-States]. PhD. Moscow: Lomonosov Moscow State University.

Voronov, A. and Glukhikh, L., 2007. Strategicheskie kommunikatsii v sisteme upravleniya promyshlennostyu Rossii [Strategic Communications in the Russian Industrial Management System]. Praktichesky marketing, 8, pp. 7-13.

VTsIOM, 2018. Nezavisimy ot SShA Internet: Illyuziya ili realnost?[An Internet Independent of the United States: Illusion or Reality?]. VTsIOM [online]. Available at: wciom.ru/analytical-reviews/analiticheskii-obzor/nezavisimyj-otssha-internet-illyuziya-ili-realnost [Accessed 18 January 2021]. 
White House, 2010. National Framework for Strategic Communication. White House Strategic Communications Report to Congress. Dated 16 March, released 17 March. Washington, DC: White House.

Yifan, S., 2019. SCO and BRICS: Prospects of Eurasian Integration with the Participation of China and Russia. Bulletin of the Moscow State Regional University (History and Political Science), 2, pp. 222-228. DOI: $10.22363 / 231306602017173469482$. 